\title{
Co-treatment of wounds in rabbit skin with equine platelet-rich plasma and a commercial ointment accelerates healing
}

\section{Associação de plasma rico em plaquetas de equino e pomada comercial no tratamento de feridas em pele de coelho}

Rodrigo Supranzetti de Rezende ${ }^{*}$ (D) , Duvaldo Eurides ${ }^{2}$ (D) , Endrigo Gabelline Leonel Alves $^{1}$ (D) , Guilherme Costa Venturini ${ }^{1}$ (D) , Rodrigo Lopes de Felipe ${ }^{3}$ (D)

1 Universidade de Uberaba, Uberaba, MG, Brazil.

2 Universidade Federal de Uberlândia, Uberlândia, MG, Brazil.

3 Faculdade Mais de Ituiutaba, Ituiutaba, MG, Brazil.

*Correspondent: rezendehvu@hotmail.com

Section: Medicina Veterinária

Received

December 13, 2018

Accepted

November 27, 2019

Published

April 22, 2020

www.revistas.ufg.br/vet visit the website to get the how to cite in the article page.

\begin{abstract}
Autologous platelet-rich plasma (PRP) is beneficial in the healing process of reconstructive surgeries, contributing to the stimulation of angiogenesis; however, heterologous plasma has been shown to be more effective. The objective of this study was to verify, by macro- and microscopic evaluation, whether PRP accelerates the healing process as compared to a commercial ointment containing gentamicin, sulfanilamide, sulfadiazine, urea, and vitamin A (study ointment). This study used 24 white New Zealand rabbits, aged 12 months, and each weighing approximately $3 \mathrm{~kg}$. The animals were separated into 4 equal groups and underwent wound induction through skin removal in the thoracic (study wound) and lumbar (control wound) dorsal midline. Study wounds were co-treated with equine PRP and the study ointment. Control wounds were treated with only the study ointment. Group I underwent histological evaluation 3 days after the skin removal procedure, group II after 7 days, group III after 14 days, and group IV after 21 days. A skin fragment was collected from each animal for histological evaluation. The co-treatment with heterologous equine PRP and the study ointment accelerated the healing process in the surgically induced skin wounds, confirming the acceleratory effect of PRP on wound healing.
\end{abstract}

Keywords: healing, skin, growth factors, platelet rich plasma.
Resumo
O plasma rico em plaquetas autólogo é importante no processo cicatricial de cirurgias reconstrutivas, auxiliando na estimulação da angiogênese; no entanto, o plasma heterólogo mostrou-se mais eficaz. Utilizou-se 24 coelhos da raça Nova Zelândia, com idade de 12 meses, com peso corporal cerca de 3,0 kg. Os animais foram separados em quatro grupos de igual número e submetidos a remoção de pele na linha média dorsal torácica (ferida tratada) e lombar (ferida controle). Nas tratadas, foi aplicado plasma rico em plaqueta de equino e pomada contendo gentamicina, sulfanilamida, sulfadiazina, ureia e vitamina A e, nas do grupo controle, somente a pomada. Nos do grupo I, foi coletado tecido cutâneo para a avaliação histológica com três dias de pós-operatório, nos do 
grupo II com sete dias, nos do grupo III com 14 dias e, nos do grupo IV, com 21 dias. Decorrido o período de avaliação de cada grupo, foi coletado fragmento de pele para avaliação histológica. O uso associado do plasma rico em plaquetas heterólogo de equino com a pomada contendo gentamicina, sulfanilamida, sulfadiazina, ureia e vitamina $A$, em feridas de pele induzidas cirurgicamente acelera o processo cicatricial.

Palavras-chave: cicatrização, fatores de crescimento, pele, plasma rico em plaquetas

\section{Introduction}

Healing is a process that restores the external physical integrity of body structures and involves complex integrations between cells and various other factors. It is a dynamic and complex process that includes tissue inflammation, proliferation, and remodeling phases $^{(1,2)}$. The healing process involves the extracellular matrix, cytokines, blood cells, and growth factors ${ }^{(1,3,2)}$.

Growth factors are proteins that stimulate and activate cell proliferation by activating angiogenesis, myelogenesis, and gene transcription, among other reactions that activate and accelerate the healing process ${ }^{(2)}$. The most important factors for wound healing include the epidermal growth factor (EGF), platelet-derived growth factor (PDGF), transforming growth factor beta (TGF-b), and vascular endothelial growth factor (VEGF) ${ }^{(4)}$.

Studies on platelet-rich plasma (PRP) aim at evaluating its growth factors, which are important in wound healing and released from platelet degranulation. The active secretion of these factors begins 10 min after platelet clotting and more than 95\% are secreted within $1 \mathrm{~h}^{(1,2)}$. When in contact with their respective nuclear receptors, they stimulate angiogenesis, tissue replication, healing, and growth of new organic structures $^{(1,3)}$. The advantage of using PRP produced from equine blood compared to autologous serum is that equine plasma contains a higher concentration of vitamins and growth factors, and as platelets remain intact, they can adhere to the tissue surface and act biologically and mechanically(3).

The healing process can be evaluated by the hematoxylin and eosin (H\&E) staining technique using several indicators, such as neutrophil exudate, interstitial edema, mucosal necrosis, transmural necrosis, fibrin deposition, vascular congestion, monomorphonuclear infiltrate, mucosal regenerative activity, fibroblastic proliferation, vascular neoformation, granulomatous process, and interstitial fibrosis ${ }^{(1,5,6)}$.

The objective of this study was to verify, by macro and microscopic evaluation, whether platelet-rich plasma accelerates the healing process compared to a commercial ointment containing gentamicin, sulfanilamide, sulfadiazine, urea, and vitamin A (study ointment). 


\section{Materials and methods}

The Animal Experimentation Ethics Committee of the University of Uberaba approved the use of 24 white male New Zealand rabbits in this experiment under no. 034/2016. The animals were healthy, with a mean age of 12 months and body weight of about $3.0 \mathrm{~kg}$. They were separated into four groups of equal numbers $(n=6)$, and considered healthy after clinical evaluations, complete blood count (CBC), and direct coproparasitological tests.

The rabbits underwent wound induction through skin removal in the dorsal thoracic and lumbar midline regions; since the animal has limited access to these regions, it will not interfere with the healing process. Two wounds were induced in each rabbit, the thoracic was considered the "treatment wound" (TW) and the lumbar was the "control wound" (CW). The thoracic wounds were treated with equine PRP and the study ointment. The lumbar wounds were treated with only the study ointment. The animals in group I had their skin tissue collected for histological evaluation at day 3 , in group II at day 7, in group III at day 14, and in group IV at day 21 postoperation (PO), totaling six treated wounds and six control wounds for each observation group. The rabbits were kept in individual cages and had free access to food and water throughout the experiment.

A healthy male quarter horse weighing $550 \mathrm{~kg}$ and aged approximately 12 years was used for platelet-rich plasma production. The animal was considered healthy after clinical evaluations, CBC, and counting of eggs per gram (EPG) of feces, and was kept in an area with Tifton 85 (Cynodon spp.) grass with free access to water and mineral supplementation.

The PRP was obtained through daily collection of $40 \mathrm{~mL}$ of blood from the external jugular vein of the horse. The blood was distributed in $4.0 \mathrm{~mL}$ tubes containing $3.2 \%$ sodium citrate. The material was centrifuged in a Celm series 4161 centrifuge for $20 \mathrm{~min}$ at 2,220 rpm (400×g) for cell separation through concentration gradient. The fraction of plasma and platelets contained in the upper part of the tube was pipetted and stored in a container, without an anticoagulant. The removed portion was centrifuged again for $10 \mathrm{~min}$ at 2,220 rpm (400×g). The upper serum component had two-thirds removed as a platelet-poor plasma and the remaining third at the bottom was considered PRP. This plasma was evaluated for platelet viability and total cell count before PRP activation with $5 \%$ calcium chloride. The platelets were manually counted in a Neubauer chamber. Counts higher $(1,158,750 \pm 202,723)$ than at least four times the initial platelet count $(250,000 \pm 180,000)$ were considered PRP and were activated by addition of $0.25 \mathrm{~mL}$ of $5 \%$ calcium chloride to each $0.5 \mathrm{~mL}$ of PRP. The solution was homogenized and rested in a thermal box with ice for approximately $10 \mathrm{~min}$ before being transported to the site where the dressings were performed ${ }^{(7)}$.

The animals underwent fasting (no water and solid food) for $6 \mathrm{~h}$, and were anesthetized with ketamine (35 mg/kg, intramuscularly (IM) (10\% ketamine hydrochloride, Vetinil, Brazil) and Sedanew (5.0 mg/kg, IM) (2\% xylazine, Vetnil, Brazil). The thoracic midline 
area was then shaved along the interscapular and iliac regions. After topical antisepsis of the surgical area with $2 \%$ chlorhexidine soap and $0.5 \%$ alcoholic chlorhexidine, two circular skin incisions were made in the thoracic midline using a $3.0 \mathrm{~cm}$ diameter circular metal mold, equidistant from each other by approximately $10.0 \mathrm{~cm}$, forming the thoracic (treated) and lumbar (control) wounds. Pain was managed with tramadol (0.5 $\mathrm{mg} / \mathrm{kg}$, IM) (tramadol hydrochloride, 50 mg/mL, União Química Farmacêutica Nacional S/A, Brazil) twice a day for 3 days.

The rabbits received the first daily dressing at 8:00 am, during which both wounds were irrigated with $0.9 \%$ sodium chloride solution and then cleaned with gauze. Then, $0.2 \mathrm{~mL}$ of equine PRP concentrate, produced on the same day and activated with $5 \%$ calcium chloride at the time of the procedure, was placed on the treated wounds at a mean concentration of 1,578,750 platelets/mm3 $( \pm 202,723)$. Control wounds received 1.5 $\mathrm{g}$ of the study ointment (Vetaglós) (gentamicin, sulfanilamide, sulfadiazine, urea, and vitamin A; Vetnil, Brazil). The second dressing was performed on both wounds at 8:00 pm after being irrigated with $0.9 \%$ sodium chloride solution, and $1.5 \mathrm{~g}$ of the study ointment (Vetaglós).

The rabbits were kept in individual cages and the wounds were evaluated with scores at the 8:00 am dressing for color (1 - light red, 2 - pink, 3 - pale, 4 - cyanotic, 5 - intense red); presence of exudate ( 0 - absent, 1 - serous, 2 - sanguineous, 3 - purulent); granulation ( 0 - absent, 1 - present); scabs (0 - absent, 1 - present); hyperemia (0 - absent, 1 - present); and edema (0 - absent, 1 - present) ${ }^{(8)}$.

The wounds were measured with a $150 \mathrm{~mm}$ digital caliper (model Mtx 316119) in the cranial-caudal and lateral directions to determine area $\left(\mathrm{cm}^{2}\right)$ and wound contraction potential (\%). The data obtained were recorded on an individual spreadsheet for each animal. The formula used to calculate wound area was $A=\pi \times R \times r,(A=$ area, $\pi=3.14$, $\mathrm{R}=$ largest wound radius, and $\mathrm{r}=$ smallest wound radius). Wound contraction potential was calculated using the formula $C P=(A i-A f) / A i \times 100$, where $C P=$ contraction potential, $A f=$ final wound area, and $A i=$ initial wound area(7).

After the observation period, the rabbits were anesthetized with a mixture of Acepran $0.2 \%(0.05 \mathrm{mg} / \mathrm{kg}$ ) (acepromazine maleate $200 \mathrm{mg} / 100 \mathrm{~mL}$, Vetnil, Brazil), ketamine $10 \%$ (30 mg/kg), and Dormium 0.5\% (0.5 mg/kg) (midazolam 5 mg/mL, União Química Farmacêutica Nacional S/A, Brazil) IM, and then euthanized with $19.1 \%$ potassium chloride (potassium chloride $191 \mathrm{mg} / \mathrm{mL}$, Isofarma, Brazil) intravenously (IV). Samples of about $3.0 \mathrm{~cm}$ were removed from the wound edges and bed, and fixed for $48 \mathrm{~h}$ in $10 \%$ common formaldehyde, dehydrated in solutions of increasing ethanol concentrations (70-100\%) stored in paraffin. The material was sectioned into $6.0 \mu \mathrm{m}$ thick cuts using a Leica microtome model 2145 to prepare histological slides.

The skin sections were stained with $H \& E$, mounted between slide and cover slip with synthetic resin and evaluated under an optical microscopy (Nikon eclipse microscope, modelE200)toassignscoresto epidermal changessuchasnecrosisand re-epithelialization, and dermal changes such as edema, hemorrhage, neovascularization, fibrosis, active hyperemia, and inflammatory infiltration. Each histological region evaluated received a score after the examination of nine microscopic fields: 0 in the absence of change, 1 for 
mild change (same change repeated in one to three microscopic fields), 2 for moderate change (same change repeated in four to six microscopic fields), and 3 for severe change (same change repeated in seven to nine microscopic fields) ${ }^{(8,9)}$.

The groups (GI, GII, GIII, and GIV) were compared for morphometric (color, granulation, scabs, hyperemia, edema, and exudate) and histological variables (necrosis, reepithelialization, active hyperemia, edema, hemorrhage, neovascularization, fibrosis, and inflammatory infiltration) using the Wilcoxon test (nonparametric data) and considering a $p$-value $\leq 0.05$ significant. The Tukey test was used to compare the groups for area and scar contraction potential (parametric data) considering a p-value $\leq 0.05$ significant. The Pearson's linear correlation was used to analyze morphometric and histological variables of control and treated wounds in the different observation groups considering a 5\% significance level. The R statistical software was used for all analyses.

\section{Results and discussion}

Platelet count after obtaining PRP was higher than the initial count $(250,000 \pm 180,000)$, with a mean of $1,578,750$ platelets $/ \mathrm{mm}^{3}( \pm 202,723)$. A study showed similar results with a mean of $1,176,933$ platelets $/ \mathrm{mm}^{3(10)}$. Platelet count should present values above $1,000,000$ platelets $/ \mathrm{mm}^{3(11)}$; however, other researchers obtained therapeutic response using concentrations above 300,000 platelets $/ \mathrm{mm}^{3(12)}$. The results obtained in this study corroborate the results by Pazzini et al. ${ }^{(8)}$, as a platelet concentration above 1,500,000 platelets $/ \mathrm{mm}^{3}$ achieved the desired therapeutic effects.

The macroscopic evaluation of experimentally induced skin wounds co-treated with heterologous equine PRP and the study ointment, showed different morphometric characteristics compared to the control wounds (Table 1). The comparison between morphological variables showed a significant difference between control and treated wounds in all groups $(P<0.05)$ in relation to the presence of serous exudate, with a higher score in treated wounds. However, it was not mentioned by Barrionuevo et al. ${ }^{(9)}$ in a study on wound healing in which autologous PRP was used as a therapeutic method. This can be justified by tissue reaction to heterologous plasma, which causes a more intense immune response.

Group II presented granulation and edema at day $7 \mathrm{PO}$, with higher scores in control wounds $(P<0.05)$ (Table 1). Similar studies showed discrete edema around the wounds treated with heterologous PRP gel in the early postoperative groups in the initial phase of the inflammatory process, which completely disappeared during subsequent evaluations ${ }^{(3)}$. The inflammatory edema seen in control wounds in group II may be justified by the postoperative traumatic process and due to the non-use of PRP, which has anti-inflammatory characteristics, since this variable was observed more frequently in control than in treated wounds.

The comparison of morphometric variables between the different groups showed that the color in control and treated wounds in group I was different from the color in the other groups $(P<0.05)$, with a light red color in wounds in group I and pink in the 
other groups (Table 1). Similar studies also reported this characteristic, with wounds remaining pink throughout the evaluation period(13,14,3,8). This variation can be due to the use of PRP as it favors local microcirculation. This finding also corroborates the results by Vendramin et al. ${ }^{(15)}$, who reported that the use of PRP in skin grafts on human pelvic limb reduced lesion size, resulted in a greater amount of granulation tissue, and presented a pink color when compared with patients who did not receive the product.

Table 1. Scores and means for morphometric variables in wounds co-treated with PRP and the study ointment, and control wounds in the different groups

\begin{tabular}{|c|c|c|c|c|c|c|c|c|}
\hline \multirow[b]{2}{*}{ Morphology } & \multicolumn{2}{|c|}{ GI } & \multicolumn{2}{|c|}{ GII } & \multicolumn{2}{|c|}{ GIII } & \multicolumn{2}{|c|}{ GIV } \\
\hline & CW & TW & CW & TW & CW & TW & CW & TW \\
\hline Color & $1.00 \mathrm{~B}$ & $1.00 \mathrm{~B}$ & $2.17 \mathrm{~A}$ & $2.38 \mathrm{~A}$ & $1.93 \mathrm{~A}$ & $2.20 \mathrm{~A}$ & $2.03 \mathrm{~A}$ & $2.19 \mathrm{~A}$ \\
\hline Granulation & $0.04 \mathrm{D}$ & $0.00 \mathrm{D}$ & $0.60 \mathrm{~B}$ & $0.52 \mathrm{C}$ & $0.77 \mathrm{AB}$ & $0.79 \mathrm{AB}$ & $0.83 \mathrm{~A}$ & $0.84 \mathrm{~A}$ \\
\hline Scabs & $0.12 C D$ & $0.04 \mathrm{D}$ & $0.60 \mathrm{ABC}$ & $0.40 \mathrm{~B}$ & $0.67 \mathrm{~A}$ & $0.68 \mathrm{~A}$ & $0.80 \mathrm{~A}$ & $0.82 \mathrm{~A}$ \\
\hline Hyperemia & $0.12 B C D$ & $0.12 \mathrm{BCD}$ & $0.19 A C$ & $0.25 \mathrm{AB}$ & $0.37 \mathrm{~A}$ & $0.22 \mathrm{AB}$ & $0.008 \mathrm{D}$ & $0.04 C D$ \\
\hline Edema & $0.67 A B$ & $0.50 \mathrm{AB}$ & $1.00 \mathrm{~A}$ & $0.17 \mathrm{~B}$ & $0.00 \mathrm{~B}$ & $0.00 \mathrm{~B}$ & $0.00 \mathrm{~B}$ & $0.17 \mathrm{~B}$ \\
\hline Exudate & $0.00 \mathrm{D}$ & $0.58 \mathrm{~A}$ & $0.00 \mathrm{D}$ & $0.38 \mathrm{AB}$ & $0.12 \mathrm{C}$ & $0.00 D$ & $0.00 \mathrm{D}$ & $0.17 \mathrm{~B}$ \\
\hline Area $\left(\mathrm{cm}^{2}\right)$ & $12.70 \mathrm{~B}$ & $13.72 \mathrm{AB}$ & $13.22 \mathrm{~B}$ & $16.47 \mathrm{~A}$ & $14.70 \mathrm{AB}$ & $9.41 \mathrm{C}$ & $10.86 \mathrm{C}$ & $7.20 \mathrm{D}$ \\
\hline$C P(96)$ & $-10.09 \mathrm{C}$ & $-8.30 \mathrm{C}$ & $-11.16 \mathrm{C}$ & $-12.20 \mathrm{C}$ & $-16.80 \mathrm{C}$ & $-28.40 \mathrm{~B}$ & $-37.00 \mathrm{~B}$ & $-46.50 \mathrm{~A}$ \\
\hline
\end{tabular}

CW: Control wound, TW: Treated wound, CP: Healing contraction potential. Mean area and contraction potential (CP) followed by different letters within the group differed in the Tukey test $(P<0.05)$. Categorical characteristic scores (color, granulation, scabs, hyperemia, edema, exudate) followed by different letters within the group differed in the Wilcoxon's test $(P<0.05)$.

The variable scabs did not differ between the control wounds $(P>0.05)$ (Figure 2: B, D, $\mathrm{F}$, and $\mathrm{H})$, but differed between groups I and II, and II and III $(\mathrm{P}<0.05)$ in treated wounds (Figure 2: A, C, E), confirming that the use of PRP induced an early formation of scabs in treated wounds compared to the control group (Table 1). Abegão et al. ${ }^{(3)}$ reported the early appearance of scabs and granulation in control wounds compared to wounds treated with PRP, starting approximately 10 days after the surgical procedure. Thus, the use of PRP may result in better healing, as presented in Table 3, which shows an intense positive and significant linear correlation $(P<0.01)$ between the granulation and scab variables $(r=0.83)$.

The evaluation of area and contraction potential showed a negative and significant linear correlation $(P<0.05)$ between these two variables $(r=-0.12)$ as presented in Table 3. All groups evaluated presented a reduction in area and contraction potential with a significant difference $(P<0.05)$ in control and treated wounds (Figure 1: C, D, E, F, G, and H), except in group I (Figure 1: A, B). For control wounds, the reduction in area was more significant in group III, while for treated wounds it was seen early in group II (Table 1). Similar result was observed for the contraction potential, where there was a negative linear correction between the two morphological variables (Table 3). Ito et al..(16), Abegão et al. ${ }^{(3)}$, and Chang et al. ${ }^{(17)}$ reported a significant decrease in both treated and control wounds during the observation period; however, the comparison between wounds showed that heterologous PRP gel had no effect in reducing the area, as compared to 
a treatment with saline solution. These different results may be related to the selection of the area where the lesion was induced, since less vascularized regions may present a delayed healing process, as also the quality and viability of the PRP produced.

Table 2. Scores for histological variables in wounds co-treated with PRP and study ointment, and control wounds in the different groups

\begin{tabular}{llllllllll}
\hline $\begin{array}{c}\text { Histological } \\
\text { characteristics }\end{array}$ & \multicolumn{2}{c}{ GI } & \multicolumn{2}{c}{ GII } & \multicolumn{2}{c}{ GIII } & \multicolumn{2}{c}{ GIV } \\
\cline { 2 - 10 } & CW & TW & CW & TW & CW & TW & CW & TW \\
\hline Necrosis & $1.83 \mathrm{~A}$ & $1.83 \mathrm{~A}$ & $0.83 \mathrm{AB}$ & $0.83 \mathrm{AB}$ & $0.67 \mathrm{AB}$ & $0.83 \mathrm{AB}$ & $0.00 \mathrm{~B}$ & $0.00 \mathrm{~B}$ \\
Re-epithelialization & $0.00 \mathrm{C}$ & $0.00 \mathrm{C}$ & $0.00 \mathrm{C}$ & $0.00 \mathrm{C}$ & $1.00 \mathrm{C}$ & $1.83 \mathrm{C}$ & $2.00 \mathrm{~B}$ & $2.67 \mathrm{~A}$ \\
Active hyperemia & $1.50 \mathrm{~A}$ & $1.20 \mathrm{~A}$ & $0.70 \mathrm{~A}$ & $0.83 \mathrm{~A}$ & $0.33 \mathrm{~A}$ & $0.83 \mathrm{~A}$ & $0.70 \mathrm{~A}$ & $0.70 \mathrm{~A}$ \\
Edema & $0.70 \mathrm{AB}$ & $0.50 \mathrm{AB}$ & $1.00 \mathrm{~A}$ & $0.20 \mathrm{AB}$ & $0.00 \mathrm{~B}$ & $0.00 \mathrm{~B}$ & $0.00 \mathrm{~B}$ & $0.20 \mathrm{AB}$ \\
Light bleeding & $1.20 \mathrm{~A}$ & $1.50 \mathrm{~A}$ & $0.20 \mathrm{~B}$ & $0.33 \mathrm{~B}$ & $0.00 \mathrm{~B}$ & $0.00 \mathrm{~B}$ & $0.33 \mathrm{~B}$ & $0.20 \mathrm{~B}$ \\
Neovascularization & $0.00 \mathrm{C}$ & $0.00 \mathrm{C}$ & $1.00 \mathrm{~B}$ & $1.33 \mathrm{~B}$ & $1.33 \mathrm{~B}$ & $2.00 \mathrm{AB}$ & $1.70 \mathrm{~B}$ & $2.50 \mathrm{~A}$ \\
Fibrosis & $0.00 \mathrm{C}$ & $0.00 \mathrm{C}$ & $0.70 \mathrm{C}$ & $1.50 \mathrm{~B}$ & $1.70 \mathrm{~B}$ & $2.33 \mathrm{AB}$ & $2.00 \mathrm{~B}$ & $3.00 \mathrm{~A}$ \\
Infiltrated & $1.00 \mathrm{AB}$ & $0.83 \mathrm{AB}$ & $1.83 \mathrm{AB}$ & $1.33 \mathrm{AB}$ & $1.33 \mathrm{AB}$ & $1.33 \mathrm{AB}$ & $1.50 \mathrm{~A}$ & $0.83 \mathrm{~B}$ \\
\hline
\end{tabular}

CW: Control wound, TW: Treated wound. Scores of categorical characteristics followed by different letters differed in the Wilcoxon's test $(P<0.05)$.

This study showed characteristics of tissue necrosis, with higher scores in group I wounds, but with no significant difference between control and treated wounds in the four groups ( $P>0.05$ ) (Table 2). The same characteristics were reported in experiments on tissue reconstitution from skin grafts associated with PRP gel; however, it was significantly higher in control wounds than in the treated ones ${ }^{(18,19,20,8)}$. Variables related to skin graft viability are associated with the recipient's vascular bed and not only with PRP use, which was not observed in the present study, in which necrosis occurred in all groups regardless of the use of PRP.

Tissue re-epithelialization was seen in group III (Figure 2: E and F), but without significant difference between control and treated wounds, with treated wounds reaching the highest score. Re-epithelialization was significantly different only in group IV $(P<0.05)$, with treated wounds (Figure 2: G) presenting higher re-epithelialization (Table 2). Other studies comparing different PRP sources showed that re-epithelialization occurred independently of the use of plasma ${ }^{(21,22,23,9)}$. However, it is important to evaluate other factors that may be related to non-significant results, such as number of platelets per microliter of blood and the period between PRP activation and use.

Active hyperemia was seen in all groups, as well as edema (Figure 2: D) and mild hemorrhage; however, these variables had a higher score in group I, with no difference between control and treated wounds $(P>0.05)$ (Table 2). Other studies have reported that PRP significantly increases inflammatory signs, contributing to tissue healing(24), which was not observed in this study, possibly due to the anti-inflammatory effect of PRP.

Tissue neovascularization started in group II; however, only group IV showed a 
significant difference $(P<0.05)$ between control and treated wounds. The same result was observed for fibrosis, which started in both wounds in group II, but with a higher score in all observations for the treated wound, especially in groups III and IV, in which there was a significant difference $(P<0.05)$ (Table 2). A significant positive linear correlation $(P<0.01)$ was also seen between neovascularization and fibrosis $(r=0.57)$, and neovascularization and inflammation $(r=0.32)$. The same positive and significant correlation $(P<0.01)$ was seen in the comparison between re-epithelialization and neovascularization $(r=0.40)$, and re-epithelialization and fibrosis $(r=0.33)$ (Table 3). The intense vascular proliferation present in wounds treated with PRP may correlate with the growth factors present in platelets, which act in the initial phase of healing like the vascular endothelial and epidermal growth factors, stimulating angiogenesis, mitogenesis, and vascular permeability, and inducing the growth of epithelial tissue(8). The results found in this study may indicate that vascular proliferation occurred due to factors present in platelets, which brought oxygen supply and nutrition to the wound, favoring the healing process.

Table 3. Linear correlation between morphometric and histological variables in wounds co-treated with PRP and study ointment, and control wounds in the different groups (GI, GII, GIII, GIV)

\begin{tabular}{|c|c|c|c|c|c|}
\hline & $\begin{array}{l}\text { Contraction } \\
\text { potential }\end{array}$ & Scabs & Neovascularization & Fibrosis & Inflammation \\
\hline Area $\left(\mathrm{cm}^{2}\right)$ & $-0.12(<0.05)$ & $-0.18(<0.01)$ & & & \\
\hline$C P(96)$ & & $-0.58(<0.01)$ & $-0.13(<0.05)$ & $\begin{array}{l}-0.24 \\
(<0.01)\end{array}$ & \\
\hline Granulation & & $0.83(<0.01)$ & $0.31(<0.01)$ & $0.36(<0.01)$ & \\
\hline Scabs & & & $0.19(<0.01)$ & $0.26(<0.01)$ & \\
\hline Re-epithelialization & & & $0.40(<0.01)$ & $0.33(<0.01)$ & \\
\hline Neovascularization & & & & $0.57(<0.01)$ & $0.32(<0.01)$ \\
\hline Fibrosis & & & & & $-0.14(<0.05)$ \\
\hline
\end{tabular}

CP: Contraction potential.

Inflammatory infiltrate was present in all groups observed, with a higher score in the control than in the treated wounds, with significant difference only in group IV $(P<0.05)$ (Table 2). Other studies have reported the presence of mononuclear and polymorphonuclear cell infiltrate, but without significant differences between the experimental groups ${ }^{(25,8)}$. PRP plays an important role in the release of mediators, inducing neovascularization and fibroplasia, and favoring the healing process. However, severe inflammation may impair healing, so heterologous PRP was able to modulate this inflammatory response by stimulating cell recruitment to the wound.

A significant negative linear correlation $(P<0.05)$ was also seen between inflammation and presence of fibrosis $(r=-0.14$ ) (Table 3 ), a fact not observed in previous studies using a similar methodology $\mathrm{y}^{(26,27,28,29,30)}$. Therefore, this experiment showed that PRP stimulates angiogenesis and re-epithelialization without generating an intense inflammatory 
Co-treatment of wounds in rabbit skin with equine platelet-rich plasma and a commercial ointment accelerates healing Rezende R.S. de et al.

process that could impair healing.
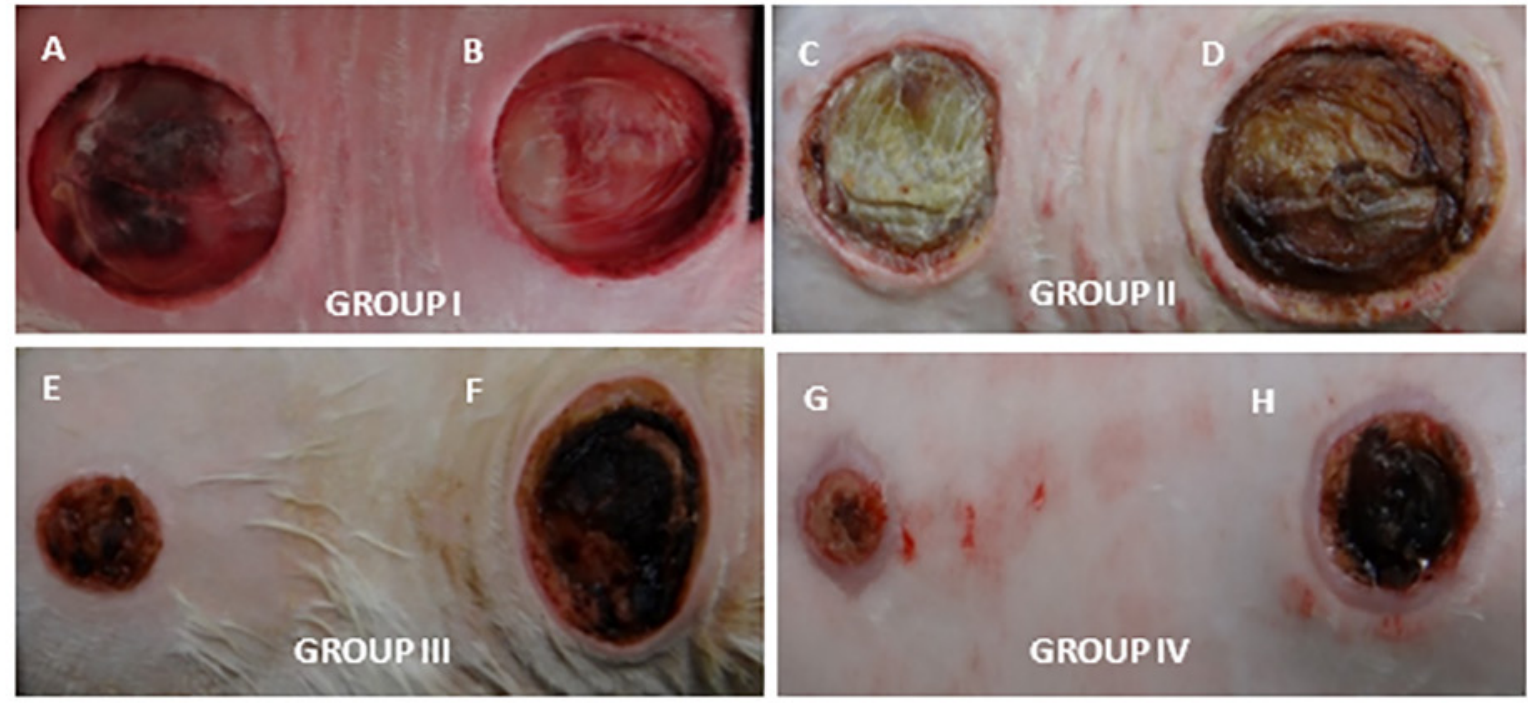

Figure 1. Wounds in groups I, II, III, and IV after 3, 7, 14, and 21 postoperative days, respectively. Similarity between the treated (A) and control wounds (B). Area reduction in the treated wound $(C, E, G)$ compared to the control wound $(D, F, H)$.
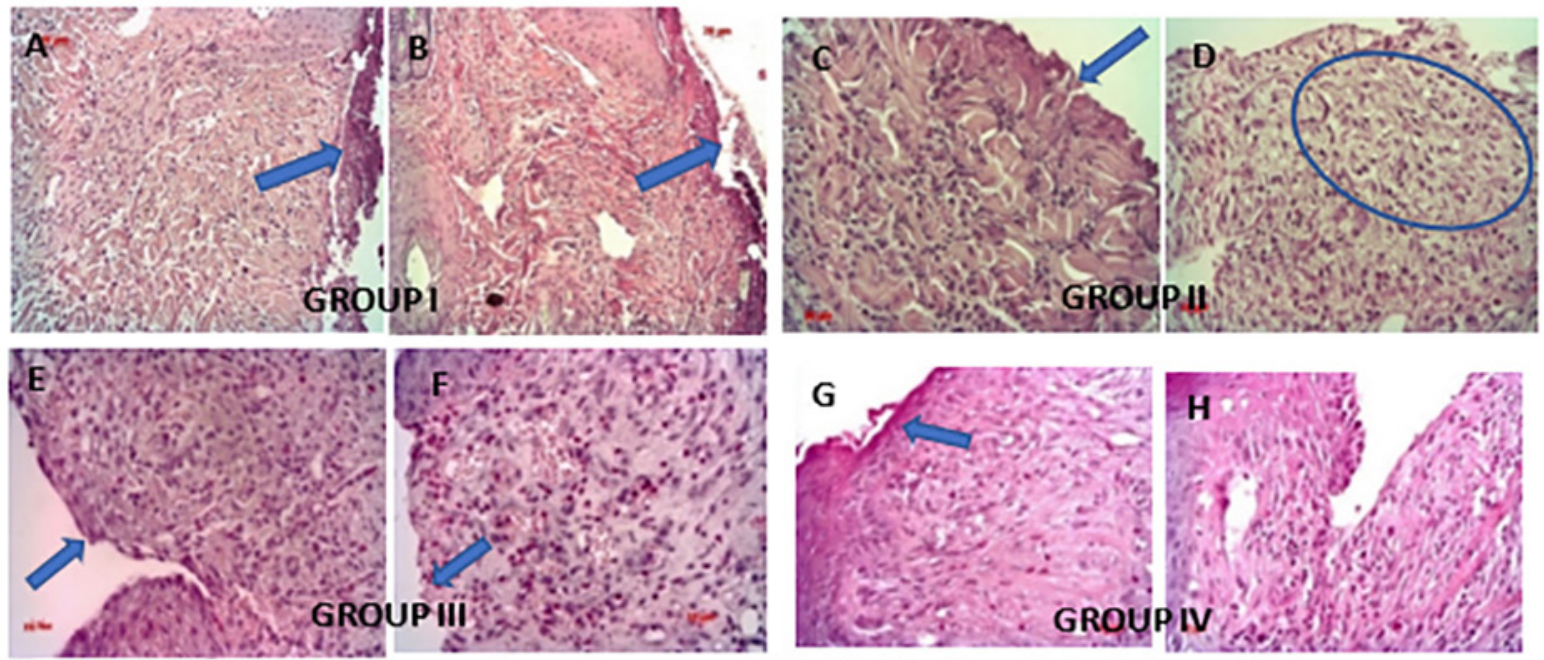

Figure 2. Photomicrographs of groups I, II, III, IV after 3, 7, 14, and 21 postoperative days, respectively. Presence of scabs in the treated (A) and control wounds (B) (arrows). Absence of scabs in the treated wound (C) (arrow). Absence of edema in the control wound (D) (circle). More intense re-epithelialization in the treated wound $(E, G)$ than in the control wound (F, H) (arrows). (HE, 40x, $20 \mu \mathrm{m})$. 
Co-treatment of wounds in rabbit skin with equine platelet-rich plasma and a commercial ointment accelerates healing Rezende R.S. de et al.

\section{Conclusion}

The co-treatment of skin wounds in rabbits with heterologous equine PRP and the study ointment accelerated the healing process.

The co-treatment with heterologous PRP and the study ointment decreased edema in the initial phase of the healing process and stimulated an anti-inflammatory action.

The wounds co-treated with PRP and the study ointment showed increased neovascularization and fibrosis with decreased inflammatory infiltration at day $21 \mathrm{PO}$.

\section{References}

1. Campos ACL, Borges-Branco A, Groth AK. Cicatrização de feridas. Arq. Bras. Cir. Dig. 2007; 20(1):51-58. https://doi.org/10.1590/S0102-67202007000100010

2. De Masi ECDJ, Campos ACL, De Masi FDJ, et al. The influence of growth factors on skin wound healing in rats. Braz. J. Otorh. 2016; 82(5):512-521. https://doi.org/10.1016/j.bjorl.2015.09.011

3. Abegão KGB, Bracale BN, Delfin, IG, et al. Effects of heterologous platelet-rich plasma gel on standardized dermal wound healing in rabbits. Acta Cir. Bras. 2015a; 30(3):209-215. https://doi.org/10.1590/S0102$\underline{865020150030000008}$

4. Ma X., Bazan HE. Increased platelet-activating factor receptor gene expression by corneal epithelial wound healing. Invest. Opht. Vis. Sci. 2000; 41(7):1696-1702.

5. Minamimura A, Ichioka S, Sano H, Sekiya N. Comparison of collagen matrix treatment impregnated with platelet rich plasma vs bone marrow. J. Plast. Surg. Hand Surg. 2014; 48(1):15-20. https://doi. org/10.3109/2000656X.2013.793193

6. Houdek MT, Wyles CC, Stalboer PGS, et al. Collagen and fractionated platelet-rich plasma scaffold for dermal regeneration. Plas. Reconst. Surg .2016; 137(5):1498-1506.

7. Eurides D, Mantovani MM, Menezes GF, et al. Efeito de concentrado de plaquetas xenólogo na cicatrização da córnea em coelhos. RPCV. 2010; 105:39-43.

8. Pazzini JM, De Nardi AB, Huppes RR, et al. Utilização de plasma rico em plaquetas para estimulação da angiogênese em flape de padrão axial toracodorsal em coelhos (Oryctolagus cuniculus). Pesq. Vet. Bras. 2016; 36(2):108-118. https://doi.org/10.1590/S0100-736X2016000200008

9. Barrionuevo DV, Laposy CB, Abegão KGB, et al. Comparison of experimentally-induced wounds in rabbits treated with different sources of platelet-rich plasma. Lab. Anim. 2015; 49(3):209-214.

10. Lehmann $P$, Sheng $P$, Lavker R, Kligman A. Corticosteroid atrophy in human skin. A study by light, scanning, and transmission electron microscopy. J. Inv. Derm. 1983; 81(2):169-176. https://doi. org/10.1111/1523-1747.ep12543603

11. Silva PSA, Del Carlo R, Serakides R, et al. Plasma rico em plaquetas associado ou não ao osso esponjoso autógeno no reparo de falhas ósseas experimentais. Ciência Rural. 2009; 3(1). https://doi.org/10.1590/ S0103-84782009000100020

12. Lima AC, Mano JF, Concheiro A, Alvarez-Lorenzo C. Fast and mild strategy, using superhydrophobic surfaces, to produce collagen/platelet lysate gel beads for skin regeneration. St. C. Ver. Rep. 2015; 11(1):161-179. https://doi.org/10.1007/s12015-014-9548-6 
Co-treatment of wounds in rabbit skin with equine platelet-rich plasma and a commercial ointment accelerates healing Rezende R.S. de et al.

13. Floryan KM, Berghoff WJ. Intraoperative use of autologous platelet-rich and platelet-poor plasma for orthopedic surgery patients. AORN J. 2004; 80(4):667-674. https://doi.org/10.1016/S0001-2092(06)61320-3

14. Weibrich G, Hansen T, Kleis W, et al. Effect of platelet concentration in platelet-rich plasma on periimplant bone regeneration. Bone. 2004; 34(4):665-671. https://doi.org/10.1016/j.bone.2003.12.010

15. Vendramin FS, Franco $D$, et al. Plasma rico em plaquetas e fatores de crescimento: técnica de preparo em cirurgia plástica. Ver. Col. Bras. Cir. 2006; 33(1):24-28. http://dx.doi.org/10.1590/S0100$\underline{69912006000100007}$

16. Ito R., Morimoto N, Pham LH, et al. Efficacy of the controlled release of concentrated platelet lysate from a collagen/gelatin scaffold for dermis-like tissue regeneration. Tis. Eng. Part A. 2013; 19(11-12):13981405. https://doi.org/10.1089/ten.tea.2012.0375

17. Chang P, Guo B, Hui Q, et al. A bioartificial dermal regeneration template promotes skin cell proliferation in vitro and enhances large skin wound healing in vivo. Oncotarget. 2017; 8(15). Disponível em: https://www.ncbi.nlm.nih.gov/pubmed/28423680. Acessado em:04 jun. 2018.

18. Brandão G. Estudo comparativo entre a eficácia clínica de enxertos ósseos (autógenos, alógenos, aloplásticos) com ou sem utilização de plasma rico em plaquetas. 2005. Disponível em: http://www. medcenter.com. Acessado em: 04 jun. 2018.

19. Kushida S, Kakudo N, Suzuki K, et al. Effects of platelet-rich plasma on proliferation and myofibroblastic differentiation in human dermal fibroblasts. Annals Plast. Surg. 2013; 71(2):219-224. https://doi. org/10.1097/SAP.0b013e31823cd7a4

20. De Souza MV, Pinto JO, Da Costa MM, et al. Quantificação de fatores de crescimento na pele de equinos tratada com plasma rico em plaquetas. Pesq. Vet. Bras. 2014; 34(6):599-612. https://doi.org/10.1590/ s0100-736X2014000600016

21. Anitua $E$, Sanchez $M$, Nurden AT, et al. Autologous fibrin matrices: a potential source of biological mediators that modulate tendon cell activities. J. Biom. Mat. Res. Part A. 2006; 77(2):285-293. https://doi. org/10.1002/jbm.a.30585

22. Plate JF, Brown PJ, Walters J, et al. Advanced age diminishes tendon-to-bone healing in a rat model of rotatorcuffrepair.TheAmer.J.Sport.Med.2014;42(4):859-868.https://doi.org/10.1177/0363546513518418

23. Abegão KGB, Bracale BN, Delfin IG, et al. Effects of heterologous platelet-rich plasma gel on standardized dermal wound healing in rabbits. Acta Cir. Bras. 2015b; 30(3):209-215, 2015b. https://doi. org/10.1590/S0102-865020150030000008

24. Guszczyn T, Surazynski A, Zareba I, et al. Differential effect of platelet-rich plasma fractions on $\beta 1$ integrin signaling, collagen biosynthesis, and prolidase activity in human skin fibroblasts. Drug. Design., Develop. Therap. 2017; 11:1849.

25. Neves PCF, Abib S, Neves RF, et al. Effect of hyperbaric oxygen therapy combined with autologous platelet concentrate applied in rabbit fibula fraction healing. Clinics.2013; 68(9):1239-1246.

26. Correia SI, Pereira H, Silva-Correia, J, et al. Current concepts: tissue engineering and regenerative medicine applications in the ankle joint. J. Roy. Soc. Int. 2014; 11(92). Disponível em: https://www.ncbi. nlm.nih.gov/pmc/articles/PMC3899856/. Acessado em: 04 jun. 2018.

27. Farghali HA, Abdelkader NA, Khattab MS, Abubakr HO. Evaluation of subcutaneous infiltration of autologous platelet-rich plasma on skin-wound healing in dogs. Biosc. Rep. 2017; 37(2). Disponível em: http://www.bioscirep.org/content/37/2/BSR20160503. Acessado em: 04 jun. 2018.

28. Rubio-Azpeitia E, Sanchez P, Delgado D, Andia I. Adult cells combined with platelet-rich plasma for tendon healing: cell source options. Orth. J. Sport. Med. 2017; 5(2). Disponível em: https://www.ncbi.nlm. 
Co-treatment of wounds in rabbit skin with equine platelet-rich plasma and a commercial ointment accelerates healing Rezende R.S. de et al.

nih.gov/pmc/articles/PMC5347436/. Acessado em: 04 jun. 2018.

29. Andrade M, Rodrigues GM, Lima DP, et al. Use of plasma rich in platelets of rabbits with few leukocytes and erythrocytes to consolidate bones. Arq. Bras. Med. Vet. Zoot. 2016; 68(2):276-282. https://doi. org/10.1590/1678-4162-8304

30. Pereira RCD, De La Corte FD, Brass KE, et al. Evaluation of three methods of platelet-rich plasma for treatment of equine distal limb skin wounds. J. Eq. Vet. Sc. 2019; 72:1-7. https://www-sciencedirect.ez177. periodicos.capes.gov.br/science/article/pii/S0737080617300266 